Vol.45, n. 3 : pp. 393-400, September 2002

ISSN 1516-8913 Printed in Brazil

\title{
Acid and Enzymatic Hydrolysis to Recover Reducing Sugars from Cassava Bagasse: an Economic Study
}

\author{
Adenise Lorenci Woiciechowski ${ }^{1}$; Saul Nitsche ${ }^{1}$; Ashok Pandey ${ }^{2}$ and Carlos Ricardo \\ Soccol $^{1 *}$ \\ ${ }^{I}$ Laboratório de Processos Biotecnológicos; Departamento de Engenharia Química; Centro Politécnico; C. \\ P.19011; 81531-970; Curitiba - PR - Brazil. ${ }^{2}$ Biotechnology Division; Regional Research Laboratory; CSIR; \\ Trivandrum - 695-019; India
}

\begin{abstract}
The objective of this work was to study the acid and enzymatic hydrolysis of cassava bagasse for the recovery of reducing sugars and to establish the operational costs. A statistical program "Statistica", based on the surface response was used to optimize the recovery of reducing sugars in both the processes. The process economics was determined considering the values of reducing sugars obtained at laboratory scale, and the operations costs of a cylindrical reactor of $1500 \mathrm{~L}$, with flat walls at the top and bottom. The reactor was operated with $150 \mathrm{~kg}$ of cassava bagasse and $1350 \mathrm{~kg}$ of water. The yield of the acid hydrolysis was $62.4 \mathrm{~g}$ of reducing sugars from $100 \mathrm{~g}$ of cassava bagasse containing $66 \%$ starch. It represented $94.5 \%$ of reducing sugar recovery. The yield of the enzymatic hydrolysis was $77.1 \mathrm{~g}$ of reducing sugars from $120 \mathrm{~g}$ of cassava bagasse, which represented 97.3\% of reducing sugars recovery. Concerning to the time, a batch of acid hydrolysis required 10 minutes, plus the time to heat and cool the reactor, and a batch of the enzymatic hydrolysis needed 25 hours and 20 minutes, plus the time to heat and to cool the reactor. Thus, the acid hydrolysis of $150 \mathrm{~kg}$ of cassava bagasse required US\$34.27, and the enzymatic hydrolysis of the same amount of cassava bagasse required US\$2470.99.
\end{abstract}

Key words: Cassava bagasse, hydrolysis, acid, enzyme, reducing sugars, economics

\section{INTRODUCTION}

Cassava (Manioca esculenta Crantz) is a plant cultivated in tropical countries. Brazil is one of the largest producers of cassava in the world. One part of cassava production in Brazil is used to obtain the cassava flour, or used directly as meal and the other part is processed to obtain starch. Industries that produce starch from the cassava roots generate daily thousands of tons of cassava bagasse as solid waste of the process. It is composed basically of fibers and residual starch that was not extracted from the cassava tubers. Cassava bagasse is generally disposed in the surrounding environment of the processing units. However, due to its high organic material content and it's high biodegradability, it could cause serious environmental pollution (Pandey et al., 2000, 2001). Starch is a polymer of glucose and contains amylose and amylopectin as building blocks. The hydrolysis of the starch present in cassava bagasse produces a broth with available reducing sugars, chiefly glucose, which could be directly fermented by microrganisms (Bobbio and Bo bbio, 1995).

\footnotetext{
${ }^{*}$ Author for correspondence
} 
Due to richness in organic matter, basically starch, cassava bagasse could be in ideal substrate for biotechnological processes where the objective could be to produce metabolites with commercial value. Cassava bagasse can be used directly in solid-state fermentation, or in submerged fermentation after hydrolysis. Table 1 shows the range of variation of its physico-chemical contents.

Table 1 - Physico-chemical composition of cassava bagasse (g/100 g dry weight)

\begin{tabular}{ll}
\hline Component & Range of content \\
\hline Humidity & $5.02-11.2$ \\
Protein & $0.32-1.61$ \\
Lipids & $0.53-1.06$ \\
Fibbers & $14.88-50.55$ \\
Ash & $0.66-1.50$ \\
Carbohydrates & $40.50-63.85$ \\
\hline
\end{tabular}

Source: (Pandey et al, 2000)

Various biotechnological processes, which involved the use of cassava bagasse as substrates include production of edible mushrooms (Beux 1995; Tonial, 1997), enzymes and, organic acids such as citric acid (Kolicheski 1995), fumáric acid (Carta, 1998; Soccol, 1994), lactic acid (Soccol et al., 1994a, 1994b), etc. Another approach to utilize cassava bagasse involves its hydrolyze to convert starch present in it into reducing sugars (mainly glucose), and then uses it in submerged fermentation to produce metabolites.

To obtain reducing sugars from cassava bagasse, it must have a thermal hydrolytic treatment with acid or enzyme. The acid or enzymatic hydrolysis of cassava bagasse produces two fractions: one liquid composed of soluble sugars from the starch hydrolysis (basically glucose), and one solid fraction composed of insoluble cellulose and fibers.

The objective of this work was to compare the recovery of reducing sugars from cassava bagasse using two different hydrolysis methods, and also to compare the cost economics of both the methods of hydrolysis.

\section{MATERIALS AND METHODS}

The physical conditions for acid and enzymatic hydrolysis were optimized using an experimental factorial design, where the response variable was the reducing sugars concentration. The response data were analyzed using the statistical program "Statistica" based on the response surface.

Acid Hydrolysis: Acid hydrolysis was performed using hydrochloric acid at $0.5,1.0$ and $1.5 \%$ concentrations. Cassava bagasse in acid solutions was submitted to a thermal treatment at different temperatures $\left(100,120\right.$ and $\left.130^{\circ} \mathrm{C}\right)$ for 5,10 and 15 minutes. The tests were made in $250 \mathrm{~mL}$ flasks, using $5 \mathrm{~g}$ of cassava bagasse and $50 \mathrm{~mL}$ of the acid solution.

Enzymatic Hydrolysis: To perform the enzymatic hydrolysis, the starch present in the cassava bagasse was pre-gelatinized by heating at $100^{\circ} \mathrm{C}$ for $15 \mathrm{~min}$. The enzymatic hydrolysis was performed in two steps. The first, using a-amylase (Termamyl 120L-Novo Nordisk), and the second using amyloglucosidase (AMG 200L-Novo Nordisk). The optimal $\mathrm{pH}$, reaction time, temperature and the enzyme concentra tion of both the steps were determined using the experimental factorial design. After the hydrolysis, the enzymes were inactivated with heat for 10 minutes at $100^{\circ} \mathrm{C}$. The tests were made in $250 \mathrm{~mL}$ flasks, using $6 \mathrm{~g}$ of cassava bagasse, and $50 \mathrm{~mL}$ of water with the appropriate enzyme (Carta, 1999).

Reducing Sugar Analysis: The reducing sugars recovered from the cassava bagasse was analyzed by Somogyi-Nelson method (Nelson, 1944; Somogyi, 1945; Somogyi, 1952).

Energy Costs: The energy costs of both the processes, viz. acid and enzymatic hydrolysis were done considering the reducing sugars recovered during the optimization studies, and a scale -up in a reactor of $1500 \mathrm{~L}$. The hydrolysis costs were calculated considering the energy and the chemicals necessary for both the processes.

Reactor: A cylindrical stainless steel reactor $(1500 \mathrm{~L})$ with thermal insulation and jacket heated was used. Its diameter was $1.0 \mathrm{~m}$, height (L) 2.15 $\mathrm{m}$, (working height $1.9 \mathrm{~m}$ ) and insulation thickness: $\mathbf{D}_{\mathbf{X}}=0.05 \mathrm{~m}$ of glass wool.

Heat Needed for the Processes: In order to compare the heat necessary by both the methods of hydrolysis, the heat necessary to increase the temperature and the heat necessary to maintain it 
during each step of the both processes was calculated as described by Hol man (1992).

\section{Heat to increase the temperature of the aqueous medium with cassava bagasse:}

$Q=m \cdot c_{p} \cdot \Delta T$

Where

$m=1500 \mathrm{Kg}(10 \%$ of cassava bagasse $=150 \mathrm{~kg}+$ $90 \%$ of water $=1350 \mathrm{~kg}$ ).

$c_{p}=3.9 \mathrm{~kJ} / \mathrm{kg}^{\circ} \mathrm{C} \rightarrow 0.1 \times 1.25 \mathrm{~kJ} / \mathrm{kg}$ (cassava bagasse) $+0.9 \times 4.18 \mathrm{~kJ} / \mathrm{kg}$ (water).

$\Delta T=$ temperature variation depending on the process step.

Heat to maintain the temperature $=$ heat lost during the processes: Here the heat lost by free convection though the cylindrical wall and through the plan wall at the top and at the bottom of the reactor was considered.

a. Through the cylindrical wall (Holman 1992):

$\mathrm{Q}=\mathrm{U} \cdot \mathrm{A}_{\text {out }} \mathbf{D} \mathrm{T}$

The global coefficient of thermal exchange for the cylindrical wall was calculated using the following expression:

$U=1 /\left[A_{\text {out }} / A_{\text {in }} h_{\text {in }}+A_{\text {out }} \ln \left(r_{\text {out }} / r_{\text {in }}\right) / 2 \pi K L+1 / h_{\text {ar }}\right]$

1.The first term was related to the convection inside the reactor. To determine the medium parameters, water was considered.

$h_{\text {in }}=N u . K_{\text {in }} / D$

$K_{\text {in }}=0.685 \mathrm{~W} / \mathrm{m} \mathrm{K}$.

For reactor heat with coil:

$N u=0.87 \operatorname{Re}^{0,62} \operatorname{Pr}^{0,33}$.

$R e=N . D^{2} \rho / \mu($ Doran 1998)

$N=3.33 \mathrm{rpm}$

$\rho=1000 \mathrm{~kg} / \mathrm{m}^{3}$

$\mu=2.3 \cdot 10^{-4} \mathrm{~kg} / \mathrm{ms}$

$\operatorname{Pr}=1.45\left(\right.$ water $\left.-120^{\circ} \mathrm{C}\right)$

2. The second term was related to the insulation of reactor wall.

$A_{\text {out }}=7.43 \mathrm{~m}^{2}$

$r_{\text {out }} / r_{\text {in }}=0.55 \mathrm{~m} / 0.5 \mathrm{~m}$

$K_{\text {glass wool }}=0.038 \mathrm{~W} / \mathrm{m} . \mathrm{K}$

3. The third term was related to the convection outside the reactor

$h_{\text {out }}=N u . K_{\text {air }} / D_{\text {out }}$

$D_{\text {out }}=1.005 \mathrm{~m}$
$K_{\text {air }}=0.0328 \mathrm{~W} / \mathrm{m} \mathrm{K}$.

For cylindrical wall:

$N u=C(G r . P r)^{m}$

Where:

$C, m=$ constants for the system

$G r=g \cdot \beta\left(T_{\text {surface }}-T_{\infty}\right) L^{3} / v^{2}$.

$g=9.8 \mathrm{~m} / \mathrm{s}^{2}$

$\beta=1 / \mathrm{T}_{\text {surface }}=310^{-3} \mathrm{~K}^{-1}$

$T_{\text {surface }}=$ considered $60^{\circ} \mathrm{C}=333 \mathrm{~K}$

$T_{\infty}=25^{\circ} \mathrm{C}=298 \mathrm{~K}$

$v=2.59 .10^{-7} \mathrm{~m}^{2} / \mathrm{s}$

$\operatorname{Pr}=0.7$ (for the air)

Gr.Pr $=7.9 .10^{9} \rightarrow$ Table: $\mathrm{C}=0.10 ; \mathrm{m}=1 / 3$

(Holmann, 1992)

b. Through the top and bottom flat walls (Holman1992):

$Q=U . A_{\text {out }} \Delta T$

The global coefficient of thermal exchange for top and bottom flat walls was calculated using the following expression:

$U=1\left[\Delta x / k_{\text {isolant }}+1 / h_{\text {out }}\right]$

1. The first term was related to the conduction through the insulation walls:

$K_{\text {isolant }}=0.038 \mathrm{~W} / \mathrm{m} \mathrm{K}$

2. The second term was related to the co nvection out side the reactor:

$h_{\text {out }}=N u . k_{\text {out }} / M$

$\mathrm{Nu}=\mathrm{C}(\mathrm{Gr} P \mathrm{Pr})^{m}$

$M=$ characteristic measure $=0.9 \mathrm{D}=0.9$

$G r=$ as above

$\operatorname{Pr}=$ as above

Gr.Pr $=7.14 .10^{8} \rightarrow$ Table: $C=0.1 ; m=1 / 3$

(Holmann1992).

3. As $h_{\text {in }} \gg \gg>h_{\text {out }}$ the term related to the convection inside the reactor was not considered for plain wall.

Total heat to maintain the temperature during the processes: The total heat necessary for the processes was calculated considering the time of each step of the process:

$Q_{t}=Q \cdot t$ 


\section{RESULTS AND DISCUSSION}

Table 2 shows the physico-chemical characteristics of the cassava bagasse used in this work, which has in general matching with those reported by Pandey et al. (2000).

Table 2 - Physico-chemical composition of cassava bagasse (g/100 g dry weight)

\begin{tabular}{ll}
\hline Component & $\mathrm{g} / 100 \mathrm{~g}$ \\
\hline Humidity & 8.50 \\
Protein & 1.52 \\
Lipids & 0.53 \\
Fibbers & 21.10 \\
Ash & 1.50 \\
Starch & 66.00 \\
\hline
\end{tabular}

Acid Hydrolysis: Figures 1 and 2 show the data obtained with cassava bagasse hydrolysis using acid. Evidently best acid hydrolysis conditions were: hydrochloric acid concentration of $1 \%$, reaction time of 10 minutes, and temperature of $120^{\circ} \mathrm{C}$, which resulted $62.4 \mathrm{~g}$ of reducing sugars from $100 \mathrm{~g}$ of cassava bagasse This value represented $94.5 \%$ of recovery of reducing sugars from the starch available in cassava bagasse.

Enzymatic Hydrolysis: According to Carta (1999), in enzymatic hydrolysis of cassava bagasse, firstly starch must be gelatinized at $100^{\circ} \mathrm{C}$ for 10 minutes. Best reaction conditions for the hydrolysis were by using $100 \mathbf{~ m L}$ of the a-amylase (Termamyl $120 \mathrm{~L} / \mathrm{g}$ starch) at $\mathrm{pH} 6.5$ for 1 hour at $90^{\circ} \mathrm{C}$. In the second step, $471 \mathrm{~mL}$ of the amyloglucosidase (AMG $200 \mathrm{~L}) / \mathrm{g}$ of starch at $\mathrm{pH} 4.5$ was used for 24 hours at $60^{\circ} \mathrm{C}$. The last step consisted of inactivating the enzymes by increasing the reaction temperature to $100^{\circ} \mathrm{C}$ for 10 minutes. Highest reducing sugars value obtained was $77.1 \mathrm{~g}$ from $120 \mathrm{~g}$ of cassava. This value represented $97.3 \%$ recovery of reducing sugars.

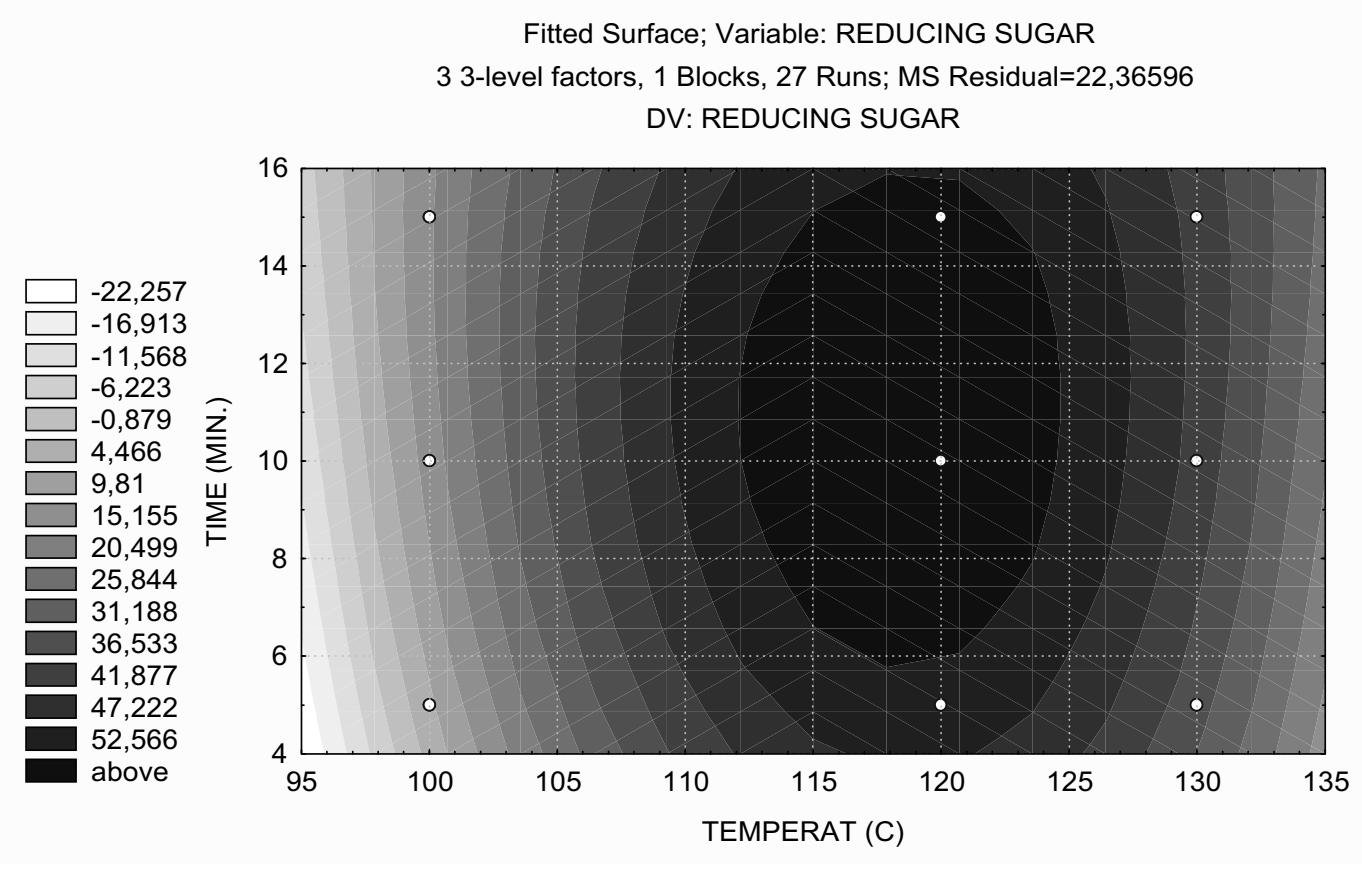

Figure 1 - Reducing Sugar recovered from the cassava bagasse, at the acid hydrolysis, according to the time and temperature used. 
Fitted Surface; Variable: REDUCING SUGAR

3 3-level factors, 1 Blocks, 27 Runs; MS Residual=22,36596

DV: REDUCING SUGAR

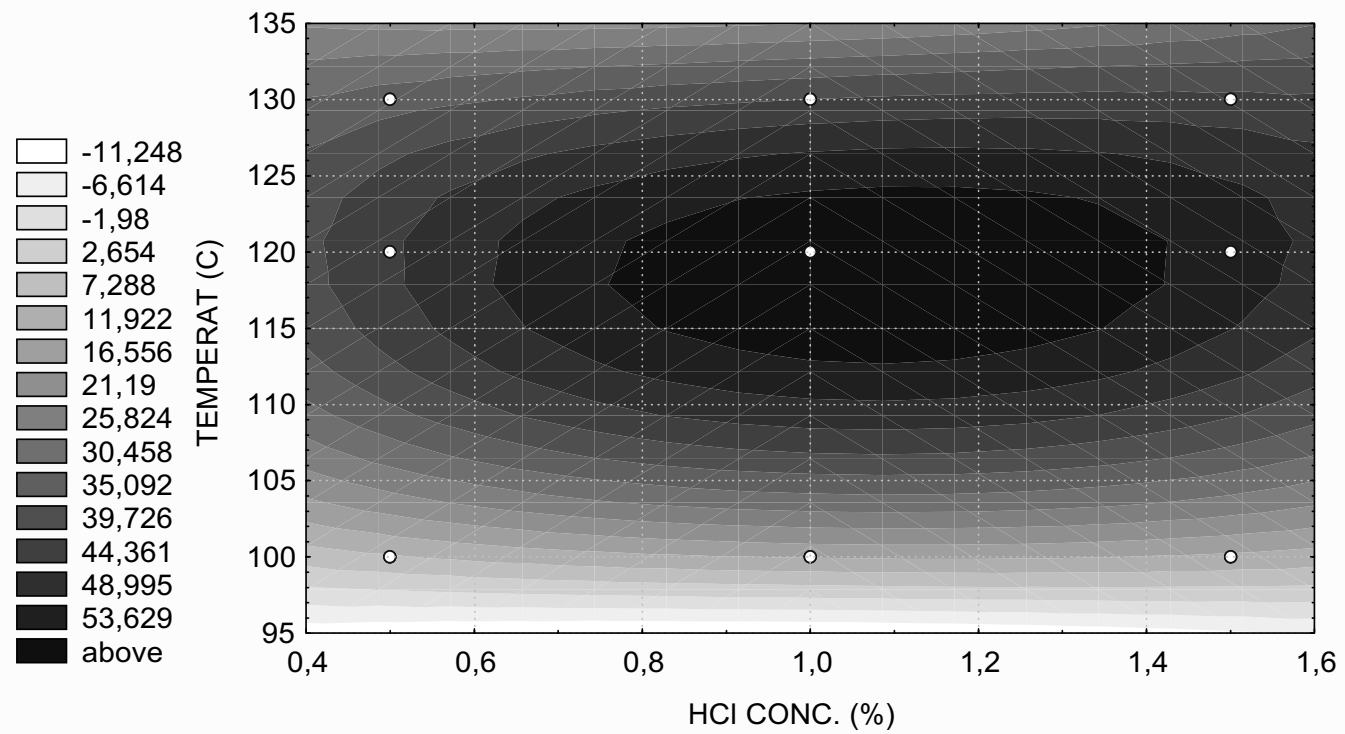

Figure 2 - Reducing sugars recovered from the cassava bagasse by acid hydrolysis, according to concentration of hydrochloric acid and temperature used.

\section{Energy Costs for the Acid Hydrolysis:}

Energy to heat the material from $25^{\circ} \mathrm{C}$ (environment temperature considered) to $120^{\circ} \mathrm{C}=$ $556 \mathrm{MJ}$ (1)

Heat lost to the environment $=550 \mathrm{~J} / \mathrm{s}$

Hydrolysis time $=10$ minutes $=600 \mathrm{~s}$

Total lost heat $=330 \mathrm{~kJ}$

Total heat required $=556.4 \mathrm{MJ}$

The total energy nec essary to the cassava bagasse acid hydrolysis was $154.1 \mathrm{kWh}$.

\section{Energy Costs for the Enzymatic Hydrolysis: Gelatinization}

Energy to heat the material from 25 to $100^{\circ} \mathrm{C}=$ $439 \mathrm{MJ}$

Heat lost to the environment $=435 \mathrm{~J} / \mathrm{s}$

Hydrolysis time: 15 minutes $=900 \mathrm{~s}$

Total heat lost $=391.5 \mathrm{k} \ldots \ldots$ (2)

Total heat required $=439.4 \mathrm{MJ} \quad \ldots . .(1)+(2)$

\section{Hydrolysis with Termamyl $120 \mathrm{~L}\left(90^{\circ} \mathrm{C}\right)$}

Heat lost to the environment $=377 \mathrm{~J} / \mathrm{s}$

Hydrolysis time $=60$ minutes $=3600 \mathrm{~s}$

Total heat lost $=1400 \mathrm{~kJ} \quad \ldots$ (2)

Total heat required $=1400 \mathrm{~kJ}$

$(1)+(2)$
Hydrolysis with AMG 200 L (609)

Heat lost to the environment $=203 \mathrm{~J} / \mathrm{s}$

Hydrolysis time $=24 \mathrm{~h}=86400 \mathrm{~s}$

Total heat lost $=18 \mathrm{MJ}$

Total heat required $=18 \mathrm{MJ} \ldots .(\mathbf{1})+(\mathbf{2})$

\section{Enzyme inactivation}

Energy to heat the material from 60 to $100^{\circ} \mathrm{C}=$ 234 MJ. .... (1)

Heat lost to the environment $=435 \mathrm{~J} / \mathrm{s}$

Inactivation time $=10 \mathrm{~min}=600 \mathrm{~s}$

Total heat lost $=261 \mathrm{~kJ} \ldots$.. (2)

Total heat required $=234.3 \mathrm{MJ} \ldots$... (1) + (2)

Total energy necessary to the cassava bagasse enzymatic hydrolysis was $692.8 \mathrm{MJ}=192.5 \mathrm{kWh}$.

Considering the costs in energy, the most advantageous process to use for the hydrolysis of the residual starch present at the cassava bagasse was the acid one. The energy consumption for the enzymatic hydrolys is was $24.92 \%$ more expensive then the acid hydrolysis, although the reactor was well insulated.

While doing these comparisons, the equipment cost was not considered, as it was the same for both the processes. 
Costs of the chemical components for the Add and Enzyme Hydrolysis of cassava bagasse (150 kg):

Tables 3 and 4 show the costs of the chemical components of acid and enzyme hydrolysis for a batch (considering the specific weight of hydrochloric acid $=1.159 \mathrm{~g} / \mathrm{L}$ and enzyme specific weight $=1.2 \mathrm{~g} / \mathrm{L}$ ), respectively.

Table 3 - Price and chemicals for the acid hydrolysis of $150 \mathrm{~kg}$ of cassava bagasse

\begin{tabular}{lllll}
\hline Product & $\begin{array}{l}\text { Conc. } \\
\%\end{array}$ & $\begin{array}{l}\text { Amount } \\
\mathrm{Kg}\end{array}$ & $\begin{array}{l}\text { Price } \\
\text { US\$ }\end{array}$ & $\begin{array}{l}\text { Total } \\
\text { Price }\end{array}$ \\
\hline $\mathrm{HCl}$ & 37 & 46.96 & 0.3 & 14.09 \\
$\mathrm{NaOH}$ & 100 & 19.04 & 1.06 & 20.18 \\
\hline Total & & & & 34.27 \\
\hline
\end{tabular}

Table 4 - Cost of chemicals for the enzymatic hydrolysis of $150 \mathrm{~kg}$ of cassava bagasse

\begin{tabular}{llllc}
\hline Product & $\begin{array}{l}\text { Conc. } \\
\%\end{array}$ & $\begin{array}{l}\text { Amoun } \\
\mathrm{t} \\
\mathrm{kg}\end{array}$ & $\begin{array}{l}\text { Pric } \\
\mathrm{e}\end{array}$ & Total Price \\
\hline $\begin{array}{l}\text { Termamyl } \\
\text { 120 L }\end{array}$ & 100 & 11.88 & $\begin{array}{l}11.5 \\
5\end{array}$ & 137.21 \\
AMG 200L & 100 & 55.95 & $\begin{array}{l}41.7 \\
0\end{array}$ & 2333.11 \\
HCl to pH & 37 & 0.979 & 0.3 & 0.29 \\
$\begin{array}{l}4.5 \\
\text { NaOH } \\
\text { (neutr.) }\end{array}$ & 100 & 0.360 & 1.06 & 0.38 \\
\hline Total & & & & 2470.99 \\
\hline
\end{tabular}

Considering the chemicals necessary for a batch, acid hydrolysis was much less expensive than the enzymatic one. Cost of chemicals was considered as an important factor because the price difference was very high, which would largely affe ct any cost analysis. The only limitation with acid hydrolysis could be the issue of toxicity, because the acid process increases the medium salinity, and it could be a limiting factor

\section{CONCLUSION}

Analysing the process yields of the recovered reducing sugars from the starch present in cassava bagasse, both processes were quite efficient and similar with $94.5 \%$ for the acid hydrolysis against $97.3 \%$ for the enzymatic hydrolysis. Looking at the time required for each process, acid hydrolysis was more advantageous than the enzymatic process. For a batch, the acid hydrolysis was completed in only 10 minutes plus the time to heat and cool the material. The enzymatic hydrolysis, on the contrast took 25 hours and 20 minutes, plus the time to heat and cool the mater ial for the whole process in a batch.

This study showed that the both methods were almost equally efficient concerning to the yield based on the reducing sugar recovered from the cassava bagasse, but economically, the acid hydrolysis was more advantageous.

\section{RESUMO}

O objetivo deste trabalho foi estudar a hidrólise acida e enzimática do bagaço de mandioca relacionando a eficiência de recuperação de açúcar redutor com os custos de operação. As condições de operação de ambos os processos foram otimizados usando o programa de análise de dados "Statistica", baseado em superfície de resposta. O estudo econômico foi feito tomando -se por base os valores de açúcar redutor obtidos nas hidrólises em escala de laboratório, e os custos de operação foram calculados para um reator de escala industrial com volume útil de $1500 \mathrm{~L}$, de paredes laterais cilíndricas, e planas no topo e no fundo. $\mathrm{O}$ reator pode operar com $136 \mathrm{~kg}$ de bagaço e 1360 $\mathrm{kg}$ de água. Para o cálculo do gasto de energia foram considerados os calores necessár ios para aquecer o material e o calor necessário para manter a temperatura do reator em cada etapa do processo. Os custos com produtos químicos foram considerados, e também o tempo de reação, que mostrou ser um ponto muito importante na definição da viabilidade do processo.

$\mathrm{O}$ rendimento da hidrólise ácida foi $62.35 \mathrm{~g}$ de açúcar redutor a partir de $100 \mathrm{~g}$ of bagaço de mandioca com $66 \%$ de amido residual. Isto representa $94.5 \%$ de açúcar redutor recuperado. $\mathrm{O}$ rendimento da hidrólise enzimática foi de $77.1 \mathrm{~g}$ de açúcar redutor a partir de $120 \mathrm{~g}$ de bagaço de mandioca com $66 \%$ de amido residual, representando $97.3 \%$ recuperação de açúcar redutor.Em relação ao tempo, uma batelada da hidrólise ácida gasta 10 minutos, mais o tempo para aquecer e resfriar o reator, e uma ba telada da hidrólise enzimática precisa de 25 horas e 20 minutos, mais o tempo para aquecer e resfriar o reator Quanto aos custos operacionais com produtos químicos e energia, a hidrólise ácida de 
$150 \mathrm{~kg}$ de bagaço de mandioca, custa US\$ 34.27 , e a hidrólise enzimática da mesma quantidade de bagaço de mandioca custa US\$2470.99.

\section{LIST OF SIMBOLS}

\begin{tabular}{|c|c|c|}
\hline$A$ & - & Area of thermal exchange, \\
\hline$A_{\text {out } / \text { in }}$ & - & area outside/inside the reactor \\
\hline$A_{\text {out }}$ & - & outside reactor area \\
\hline$C, m$ & - & Constants for the system \\
\hline$D$ & - & inside diameter \\
\hline$D_{\text {out }}$ & - & Reactor outside diameter \\
\hline$g$ & - & acceleration of gravity \\
\hline$G r$ & - & Grashof number \\
\hline$h$ & - & $\begin{array}{l}\text { convective coefficient of thermal } \\
\text { exchange }\end{array}$ \\
\hline$h_{\text {in }}$ & - & $\begin{array}{l}\text { convective coefficient inside the } \\
\text { reactor }\end{array}$ \\
\hline$h_{\text {out }}$ & - & $\begin{array}{l}\text { convective coefficient outside the } \\
\text { reactor }\end{array}$ \\
\hline$K$ & - & thermal conductivity \\
\hline$K_{\text {in }}$ & - & inside thermal conductivity \\
\hline$K_{\text {glass wool }}$ & - & glass wool thermal conductivity \\
\hline$K_{\text {air }}$ & - & air thermal conductivity \\
\hline$L$ & - & wall height \\
\hline$N$ & - & agitation \\
\hline$N u$ & - & Nusselt number \\
\hline $\operatorname{Pr}$ & - & Prandtl number \\
\hline Q & - & Heat \\
\hline$r_{\text {out }} / r_{\text {in }}$ & - & $\begin{array}{l}\text { reactor outside/inside ratio } \\
\text { conductivity }\end{array}$ \\
\hline $\mathrm{Re}$ & - & Reynolds number \\
\hline $\mathrm{t}$ & - & time \\
\hline$T_{\text {surface }}$ & - & wall temperature \\
\hline$T_{\infty}$ & - & environment temperature \\
\hline$U$ & - & $\begin{array}{l}\text { Global coefficient of thermal } \\
\text { exchange }\end{array}$ \\
\hline$\Delta T$ & - & temperature degree. \\
\hline$\Delta x$ & - & isolant wall thickness \\
\hline$\beta$ & - & $\begin{array}{l}\text { thermal coefficient of expansion }= \\
1 / \mathrm{T} \mathrm{vc}\end{array}$ \\
\hline$\mu$ & - & medium viscosity \\
\hline$v$ & - & kinematic viscosity. \\
\hline$\rho$ & - & medium density \\
\hline
\end{tabular}

\section{REFERENCES}

Beux, M. R. (1995), Biofermentação de rsíduos agroindustriais do Estado do Paraná no cultivo do fungo saprófita comestível Lentinula edodis (shiitake). Dissertação de Mestrado. Departametno de Engenharia Química. Universidade Federal do Paraná. Curitiba. 130 pp.

Bobbio, F. and Bobbio, P. (1995), Introdução à Química de Alimentos. 2. ed. São Paulo : Varela. 223 pp.

Cabello, C. (1995), Identificação de parâmetros para monitoramento de processo contínuo de hidrólise enzimática, na produção de glicose a partir da fécula de mandioca. Dissertação de Doutorado. Faculdade de Ciências Agronômicas - UNESP.

Carta, F. S. (1999), Hidrólise Enzimática de Bagaço de Mandioca e Produção de ácido fumárico por fermentação do fungo Rhizopus. Dissertação de Mestrado. Departamento de Engenharia Química. Universidade Federal do Paraná, Curitiba.

Doran, P. H. (1998), Principios de Ingenieria de los Bioprocessos. Translation from the original in English by Francisco Garcia Libiano. Ed. Acríbia S.A. Zaragoza. 468 pp.

Holman, J. P. (1992), Heat Transfer. $7^{\text {th }}$ ed. Mc.GrawHill: Singapore, $712 \mathrm{pp}$.

Kolicheski, M. B. (1995), Produção de ácido cítrico por fermentação no estado sólido utilizando como substrato bagaço de mandioca. Dissertação de Mestrado. Departamento de Engenharia Química. Universidade Federal do Paraná. 135 pp.

Nelson, N. (1944), A photometric adaptation of Somogyi method for the determination of glucose. Journal of Biological Chemistry, 153, 375-380.

Pandey, A., Soccol, C. R.; Nigam, P. and Soccol, V. T. (2000), Biotechnological potencial of agro-industrial residues: II Cassava Bagasse. Bioresource Technology, 74, 81-87.

Pandey, A.; Soccol, C. R.; Rodrigues-Leon, J. A. and Nigam, P. (2001), Solid-State Fermentation in Biotechnology. Asiatech Publishers, Inc. Nova Delhi. Índia. $221 \mathrm{pp}$.

Soccol, C. R.; Woiciechowski, A. L. and Pandey A. (2000), Brazillian patente deposited at INPI Instituto Nacional de Propriedade Industrial. N 1544 de 28.12.2000.

Soccol, C. R. (1994), Contribuição ao Estudo da Fermentação no Estado Sólido em Relação com a Produção de Ácido Fumárico, Biotransformação de Resíduo Sólido de Mandioca por Rhizopus e Basidiomacromicetos do Gênero Pleurotus. Tese de Concurso Público de Professor Titular em Biotecnologia e Tecnologia de Alimentos. Universidade Federal do Paraná. Curitiba. 
Soccol, C. R.; Marin, B. and Raimbault, M. (1994a), Potential of Fermentation for Production of L(+)Lactic Acid by Rhizopus oryzae. Applied Microbiology and Biotechnology, 41, 286-290

Soccol, C. R.; Stonoga, V. I. and Raimbault, M. (1994b), Production of L-lactic acid by Rhizopus species. World Journal of Microbiology and Biotechnology, 10, 433-435

Somogyi, M. (1945), A new reagent for the determination of sugar. Journal of Biological Chemistry, 160, 61-68.

Somogyi, M. (1952), Notes on sugar determination. Journal of Biological Chemistry, 195, 19-23.
Tonial, T. M. (1997), Otimização do crescimento do fungo comestível Volvariella volvacea em fermentação no estado sólido e em fermentação submersa a partir de resíduos agroindustriais. Dissertação de mestrado. Departamento de Engenharia Química. Universidade Federal do Paraná. Curitiba.
Received: October 19, 2001; Revised: March 26, 2002; Accepted: May 09, 2002. 